\title{
The motivational function of an objective in physical activity and sport
}

\author{
Mariusz Lipowski ${ }^{1 \cdot A, B, C, D, E, F, G}$, Anna Ussorowska $a^{2 \cdot C, D, E, F}$ \\ 1: Department of Health Psychology, Gdansk University of Physical Education and Sport, Gdansk, Poland \\ 2: Institute of Psychology, University of Gdansk, Gdansk, Poland
}

\section{BACKGROUND}

As a conscious activity of an individual, physical activity (PA) constitutes an element of the free-time dimension. The type of goal allows us to distinguish between sport and PA: sport performance vs. psychophysical health. Drawing on the theory of the motivational function of an objective, this study examined the motivational function of an objective in physical activity and sport.

\section{PARTICIPANTS AND PROCEDURES}

The sample consisted of 2141 individuals: 1163 women aged $16-64$ years $(M=23.90, S D=8.30)$ and 978 men aged $16-66$ years $(M=24.50, S D=9.40)$ who completed the Inventory of Physical Activity Objectives (IPAO), which includes the following scales: 1) motivational value, 2) time management, 3) persistence in action, and 4) motivational conflict. There are also questions that allow one to control for variables such as the variety of forms, duration, and frequency of PA, and socio-demographic variables.
RESULTS

Males presented different motives of physical activity than females. Motives related to shapely body and health were more important for females. The most important motives for males were physical fitness and shapely body. The gender of participants moderates the motivational value of the specific objectives of physical activity and persistence in action.

\section{CONCLUSIONS}

With knowledge about the purposefulness of actions, it is possible to support and shape additional motivation experienced by an individual, by setting new, realistic objectives.

\section{KEY WORDS}

motivation; sport psychology; exercises; pro-health behaviour; goal-oriented behaviour

CORResPonding AUthor - Prof. Mariusz Lipowski, Department of Health Psychology, Gdansk University of Physical

Education and Sport, 1 Kazimierza Górskiego Str., 80-336 Gdansk, Poland, e-mail: mariusz.lipowski@awfis.gda.pl Authors' contribution - A: Study design · B: Data collection · C: Statistical analysis · D: Data interpretation ·

E: Manuscript preparation · F: Literature search · G: Funds collection

TO CITE THIS ARTICLE - Lipowski, M., \& Ussorowska, A. (2018). The motivational function of an objective in physical

activity and sport. Current Issues in Personality Psychology, 6(1), 57-66.

RECEIVED 02.04.2017 · REVIEWED 02.05.2017 • ACCEPTED 21.08.2017 • PUBLISHED 14.12.2017 


\section{BACKGROUND}

When considering the role of physical activity, it is impossible to overlook the complexity of the reasons for its undertaking - they usually determine the level of engagement, and significantly contribute to the desire to either continue the activity or to drop it ( $\mathrm{Li}$ powski, 2006). Zaleski defines a goal as "a future state that is cognitively represented, possible to achieve, has a value and regulatory power, and is pursued by an individual through their actions" (Zaleski, 1991, p. 60). In a way, this expands on the line of thought of scholars such as Tomaszewski (1979), who defines a goal as an anticipated final situation, and Kozielecki (1987), who describes a goal as a projected state that an individual intends to achieve after undertaking action. A slightly different definition is given by Pervin (1993): "a goal can be defined as a mental image or other endpoint representation associated with affect towards which action may be directed". The meaning of goals differs - their functions can be behavioural, emotional, orientational, or social (Kreitler \& Kreitler, 1994). Kozielecki (2000) believes that goals directly regulate behaviours, serving indispensable functions in the course of activities.

The right strength of motives facilitates overcoming difficulties arising in the process of setting life goals. An adequately strong motive causes the individual to concentrate on the goal of their actions. The contentment of reaching a goal is an appropriate motivation for planning increasingly difficult goals. Strong motivation also eliminates competing motives, i.e. interest in other matters such as taking a rest or watching TV (Blecharz, 2002).

Nuttin (2014) believes that goals are an important element in the motivational process, and needs are the source of goals. Setting goals makes for a cognitive fulfilment of a need and to some extent it eliminates the motivational tension that arises. Bandura (1989) believes that goals that we set for ourselves motivate us more than do those that are set for us by other people. Zaleski (1991) states that the more certain the achievement of the goals is, the greater the motivational strength it possesses. He believes that goals have a motivational function when they are significant, creative, are of some value to the individual or to other persons, and when they are situated in the long-term future. On the other hand, imposed goals have a lower motivational value. Franken (2005) believes that goals imposed by others have motivational value only when the person is engaged in their realisation.

One can look at the goals of physical activity from many perspectives. The analysis not only considers the process of setting goals, but also the goals that are already set and are in the process of being realised - their regulatory influence on action is of interest.
The starting point of the considerations in this paper is the suggested influence of goals on behaviour, because "behaviour measured in a predefined way is a criterion for the assessment of the motivational role of a goal” (Zaleski, 1991, p. 147).

\section{MOTIVES FOR UNDERTAKING PHYSICAL ACTIVITY}

The results of a 2013 population survey by Poland's Centre for Public Opinion Research (CBOŚ) showed that $66.00 \%$ of respondents had done sports or other kinds of physical activity in the year preceding the study, where $40.00 \%$ undertook regular physical activity and $26.00 \%$ engaged in such activity sporadically. It seems important to ask about the motives of undertaking physical activity. Poles indicated most frequently the health $(70.00 \%)$ and the hedonistic $(61.00 \%)$ aspects. Almost half of those undertaking physical activity stated that they work out for improved well-being, in order to work off stress, and to be in good form (47.00\%).

Research by Molanorouzi, Khoo, and Morris (2015) on a Malaysian sample of 703 men and 657 women showed that motives for participation differ depending on age, sex, and type of activity, where women, to a larger extent than men, were interested in the improvement of their looks and physical condition, whereas men were more interested in competition. In participants aged below 40 years, physical activity was undertaken for self-improvement and for the pleasure associated with physical effort, while among people aged above 40 years, improvement of mental condition and the expectations of others turned out to be more important.

Similar conclusions with regards to behaviours were presented in research by Lipowski (2006). The main goal of women undertaking physical activity was to improve their physique and to maintain it, as well as the improvement and maintenance of physical fitness. Health and well-being are less frequent reasons women undertake physical activity. Among the most important goals declared, $37.00 \%$ involved a state that is to be obtained and $47.00 \%$ were of a continuous character.

A different research perspective was assumed by Aaltonen, Rottensteiner, Kaprio, and Kujala (2014), who investigated the motives of individuals sporadically engaging in physical activity (inactive) and individuals who regularly work out (active). For both the active $(n=1202)$ and inactive $(n=1106)$ participants, the most important motive for undertaking physical activity transpired to be a willingness to be in good physical condition as well as to improve their mental health. The only motive that was more important for the inactive individuals was the expectations of others. 
Olszewski-Strzyżowski and Dróżdż (2014) believe that individuals with higher education and awareness of the health benefits associated with physical activity engage in physical activity more often, and they are guided mostly by health motives.

\section{METHODS FOR THE MEASUREMENT OF PHYSICAL ACTIVITY GOALS}

Conclusions regarding the goals of physical activity are, in many cases, in agreement; however, the complexity of this phenomenon is associated with the necessity to develop and modify tools allowing the measurement of motives for undertaking physical activity. Researchers differ in terms of their approaches to the development of standardised tools for measuring the contributions of motives for undertaking physical activity (Rogers, Morris, \& Moore, 2008) and different tools used to measure motives for undertaking physical activity are based on different theories.

The Exercise Motivation Scale (Li, 1999), building upon Deci and Ryan's (1985) self-determination theory, consists of seven subscales measuring three types of internal motivation, three types of external motivation, as well as a demotivation subscale. The Sport Motivation Scale (Pelletier et al., 1995) and the Exercise Motivation Inventory (Markland \& Hardy, 1993) are based on the Self Determination Theory (SDT), in particular the intrinsic and extrinsic components of this theory (Deci \& Ryan, 1985).

Ryan and Frederick (1993) developed the Motivation for Physical Activity Measure (MPAM). The authors, wanting to compare motives for engaging in physical activity, conducted a study on a group of people $(n=40)$ training Tae Kwon Do $(n=24)$ or aerobics $(n=16)$. For individuals doing Tae Kwon Do, motives associated with pleasure and competence were of greater importance, while for individuals engaging in aerobics, the body-related motives were the most important (Ryan, Frederick, Lepes, Rubio, \& Sheldon, 1997). A subsequent version of MPAM-R was extended to include social motives, while health motives were divided into motives associated with fitness and appearance. Ryan et al. used the new version - MPAM-R - when conducting a study on university students $(N=155)$ who were enrolled in the university fitness club. The desire to belong to the club turned out to be associated with motives such as enjoyment, competence, social interaction, and fitness, but not with improvement of appearance (Ryan et al., 1997).

The theoretical foundation of another questionnaire - The Perception of Success Questionnaire for Exercise (POSQ-E) - is the orientation towards either the task or the ego (Ames, 1992; Zizzi, 2006). The POSQ-E was created to measure two types of goal-orientations. The first one is the orientation towards a task or mastery, and the second is orienta- tion towards ego or competitiveness. Interestingly, the results obtained from the POSQ explained about $50 \%$ of the variance, showing that there are further variables to be taken into account (Ryan et al., 1997). The authors of the POSQ questionnaire suggest its use in competitive sport, which narrows its comprehensiveness.

Molanorouzi (2014) wanted to create a more utilitarian tool, and developed the Physical Activity and Leisure Motivation Scale (PALMS). It is a comprehensive tool for the measurement of motivations of individuals engaging in physical activity. The 40 -item scale is intended to assess teenagers and adults. A study conducted with 1360 participants using the PALMS questionnaire confirmed the author's assumptions that motives for engaging in physical activity are different depending on the type of activity, age, and gender of the subjects.

A tool based on the Theory of the Motivational Function of Objective, which allows it to be applied to physical activity, is the Inventory of Physical Activity Objectives (IPAO), developed by Lipowski and Zaleski (2015). Based on factor analysis (Cronbach's $\alpha=.78$ ) and on how particular items are in line with the Theory of the Motivational Function of Objective, four scales have been distinguished: Motivational Value, Time Management, Persistence in Action, and Motivational Conflict (Lipowski \& Zaleski, 2015). The IPAO is useful in research in the areas of psychology, medicine, and sport science. Moreover, it can be used by practitioners - e.g. personal trainers assessing motives for undertaking physical activity and sports, physicians promoting physical activity, and therapists who include physical activity as a remedial tool in the therapeutic process (Lipowski \& Zaleski, 2015). The aim of this paper is to outline the goals of sports and amateur physical activity in a sample that was used in the validation process of the IPAO.

\section{PARTICIPANTS AND PROCEDURE}

\section{PARTICIPANTS}

The sample consisted of 2141 individuals: 1163 women aged $16-64$ years $(M=23.90, S D=8.30)$ and 978 men aged $16-64$ years $(M=24.50, S D=9.40)$. These were recreationally physically active individuals ( $n=1733)$ and individuals engaging in competitive sports $(n=408)$. Participants were recruited from randomly chosen fitness and sports clubs throughout Poland.

\section{RESEARCH TOOL}

The Inventory of Physical Activity Objectives (IPAO), developed by Lipowski and Zaleski, is used to assess 
the motivational function of an objective of physical activity. Physical activity (PA) is understood as physical recreation activities or sports (requiring physical effort) that are undertaken in a person's free time.

The IPAO includes questions that allow for the controlling of variables such as the variety of forms, volume, frequency of PA, and socio-demographic variables. Participants are also asked about their engagement in competitive sports (both currently and in the past) as well as their attitude towards passive engagement in sports (e.g. as a fan). Alongside the 12 objectives, there is a Likert-type scale (1-5), and the respondent is asked to assess to what extent the presented goals of PA are important for them. The subsequent part of the questionnaire concerns the motivational function of the PA objectives.

Based on factor analysis (Cronbach's $\alpha=.78$ ) and the degree to which each of the given items conformed to the theory of the motivational function of an objective, the following scales were distinguished: 1) motivational value (the extent to which the objective influences the actions undertaken by an individual),

2) time management (the level of focus on planning, arranging, and devoting time to PA),

3) persistence in action (the effectiveness and persistence of action, and the ability to deal with adversity), and

4) motivational conflict (the level of conflict - PA objectives vs. other objectives).

As well as these dimensions, the test also measures the multidimensionality of objectives. Raw scores were transformed into sten values.

Table 1

The frequency of choice of particular objectives of $P A$ as the most important

\begin{tabular}{|c|c|c|}
\hline Objectives of PA & $\sigma^{\pi}$ & ㅇ \\
\hline Health & $14.80 \%$ & $18.20 \%$ \\
\hline Physical fitness & $24.30 \%$ & $12.20 \%$ \\
\hline Company of other people & $5.50 \%$ & $3.90 \%$ \\
\hline Shapely body & $17.50 \%$ & $28.20 \%$ \\
\hline Wellbeing & $17.00 \%$ & $16.40 \%$ \\
\hline Being fit according to fashion & $0.70 \%$ & $0.60 \%$ \\
\hline Boosting confidence & $2.80 \%$ & $1.30 \%$ \\
\hline Pleasure from PA & $9.20 \%$ & $7.90 \%$ \\
\hline Escape from everyday life & $2.10 \%$ & $4.00 \%$ \\
\hline Managing stress & $3.70 \%$ & $4.00 \%$ \\
\hline Fulfilling the need for activity & $2.20 \%$ & $3.00 \%$ \\
\hline $\begin{array}{l}\text { Promoting PA by setting } \\
\text { a behaviour example }\end{array}$ & $0.30 \%$ & $0.40 \%$ \\
\hline
\end{tabular}

\section{STATISTICAL ANALYSES}

Means, standard deviations, medians, and percentage values of the investigated variables were calculated. Mann-Whitney $U$ tests were used in order to compare groups regarding the importance of physical activity objectives, because these variables are ordinal (Carifio $\&$ Perla, 2007). The relationship between age and the intensity of PA was expressed using Pearson's $r$ correlation coefficient. The relationship between particular objectives of PA was expressed using Spearman's $\rho$ correlation coefficient. The relationship between gender and engagement in competitive sports was expressed using the $\phi$ coefficient, and the relationship between the importance of particular PA objectives and age and intensity of PA was expressed as a biserial correlation coefficient. The relationship between the importance of particular goals and gender and engagement in competitive sports was expressed using the rank-biserial coefficient $r_{r b}$, and the relationship between age and PA intensity was expressed using the point-biserial correlation coefficient $r_{p b}$. In order to verify the relationship between the motivational value of an objective and the number of hours devoted to PA, a hierarchical regression analysis was conducted, controlling for gender, age, and engagement in competitive sports. The effects of interaction between the motivational value of an objective, gender, and engagement in competitive sports were also taken into account in the analysis. In the first step, gender, age, and whether one engages in competitive sports were introduced. In the second step, the motivational value of an objective was introduced; and in the third step, two interactions between the motivational value of an objective, gender, and engagement in competitive sports were introduced. In association with the assumptions of linear regression - normal distribution, homoscedasticity, and collinearity of variables were verified. Two-tailed tests were applied with $\alpha=.05$. All analyses were conducted in the IBM SPSS 24 program, using a PROCESS macro (Hayes, 2013).

\section{RESULTS}

\section{DESCRIPTIVE STATISTICS}

The frequency of choice of particular objectives of PA as the most important is presented in Table 1. Means, medians, standard deviations, percentage values, and correlation coefficients of the investigated variables are presented in Table 2. The motivational value of a goal had a positive relationship with every PA objective as well as engagement in competitive sports. Gender was associated with the motivational value of objective (a higher motivational value of objective among women), as well as objectives such as company, body shape, pleasure, fulfilling the need for 


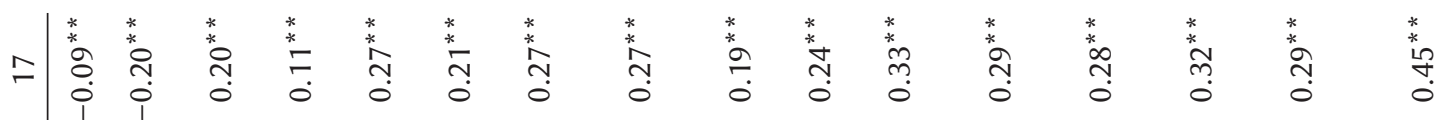

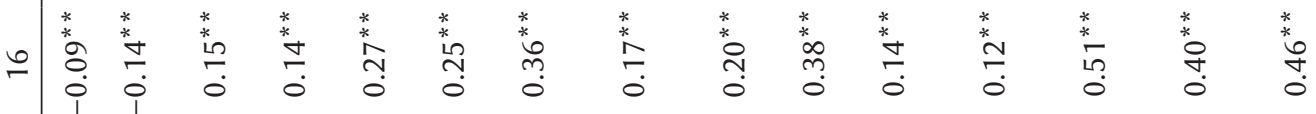

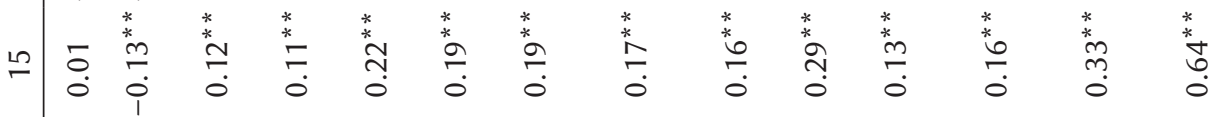

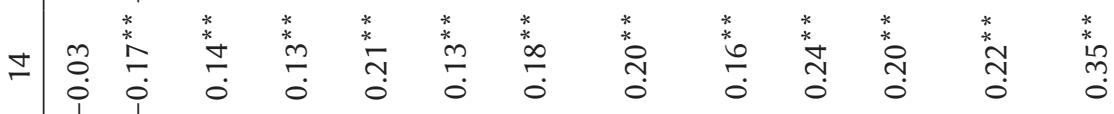

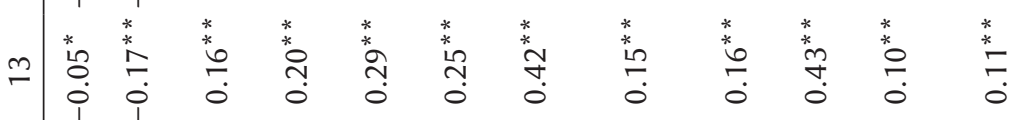

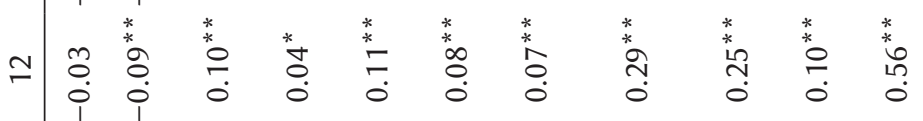

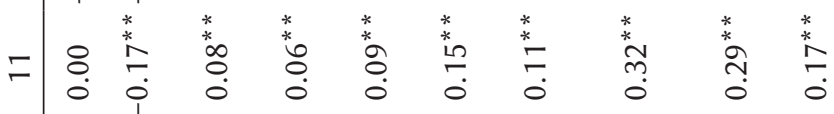

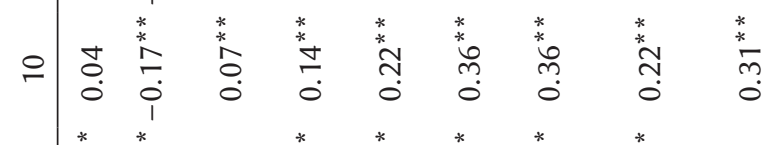

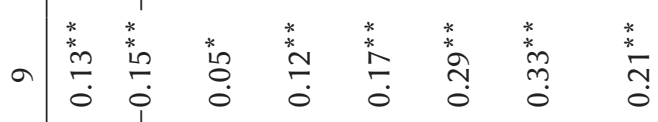

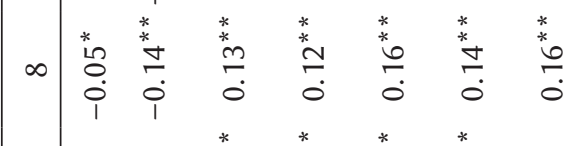


activity, and promoting physical activity. Engaging in competitive sports was positively associated with all PA objectives apart from health, and it was negatively associated with age and gender (being more frequent among men).

\section{COMPARISON OF GROUPS IN TERMS OF IMPORTANCE OF OBJECTIVES}

The participants' scores were divided both with regards to gender and engagement in competitive sports. Mann-Whitney $U$ test results are presented in Table 3 and 4 . Table 3 shows the comparison of results of men and women with the division into competitive sportsmen and amateurs. Men are the refer- ence group; therefore, a negative $\mathrm{Z}$ statistic means that women have higher scores. Table 4 is a comparison of the scores of competitive sportsmen and amateurs divided by gender. Amateurs are the reference group; therefore, a negative $\mathrm{Z}$ statistic means that individuals engaging in competitive sports have higher scores.

\section{REGRESSION ANALYSIS}

The variables introduced in the first step explained $9.70 \%$ of the variance in the hours devoted to PA, $F(3,2137)=76.42, p<.001$. In this step, significant predictors of PA intensity were age $(\beta=-.11, p<.001)$ and engagement in competitive sports $(\beta=.27$,

Table 3

Comparison of results of men and women with the division into competitive sportsmen and amateurs

\begin{tabular}{|c|c|c|c|c|c|c|c|c|c|}
\hline \multirow[t]{2}{*}{ Objectives } & \multirow[t]{2}{*}{ Gender } & \multicolumn{4}{|c|}{ Competitive sports } & \multicolumn{4}{|c|}{ Amateurs } \\
\hline & & Me & $U$ & $Z$ & $p$ & Me & $U$ & $Z$ & $p$ \\
\hline \multirow{2}{*}{ Health } & 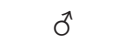 & 4 & \multirow{2}{*}{19759.0} & \multirow{2}{*}{-0.43} & \multirow{2}{*}{.665} & 4 & \multirow{2}{*}{344384.0} & \multirow{2}{*}{-2.42} & \multirow{2}{*}{.016} \\
\hline & 우 & 4 & & & & 5 & & & \\
\hline \multirow{2}{*}{ Physical fitness } & 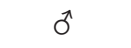 & 5 & \multirow{2}{*}{19188.5} & \multirow{2}{*}{-1.05} & \multirow{2}{*}{.294} & 5 & \multirow{2}{*}{362211.5} & \multirow{2}{*}{-0.55} & \multirow{2}{*}{.580} \\
\hline & 우 & 5 & & & & 4 & & & \\
\hline \multirow{2}{*}{ Company of others } & $\sigma^{\pi}$ & 4 & \multirow{2}{*}{19157.5} & \multirow{2}{*}{-0.97} & \multirow{2}{*}{.333} & 4 & \multirow{2}{*}{357939.5} & \multirow{2}{*}{-0.95} & \multirow{2}{*}{.341} \\
\hline & 우 & 4 & & & & 4 & & & \\
\hline \multirow{2}{*}{ Shapely body } & $\sigma^{\pi}$ & 5 & \multirow{2}{*}{20048.0} & \multirow{2}{*}{-0.17} & \multirow{2}{*}{.864} & 4 & \multirow{2}{*}{302456.0} & \multirow{2}{*}{-6.80} & -001 \\
\hline & q & 5 & & & & 5 & & & -.001 \\
\hline & $\sigma^{\pi}$ & 5 & & & & 5 & & & \\
\hline vecinding & 우 & 5 & 19003.0 & -1.20 & .232 & 5 & 345903.0 & -2.07 & .010 \\
\hline Fashion for PA & $0^{\pi}$ & 3 & 196460 & -051 & 610 & 3 & 3625420 & 048 & 620 \\
\hline & q & 3 & 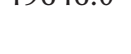 & 1 0.05 & .070 & 3 & 302042.0 & -0.40 & .023 \\
\hline Boosting & $\sigma^{\pi}$ & 4 & 102060 & $16+2+2>0$ & 100 & 3 & & 0 & 601 \\
\hline confidence & ㅇ & 3 & 10370.0 & -1.00 & .107 & 3 & 303212.0 & -0.41 & (001 101 \\
\hline Dloran from DA & $\sigma^{2}$ & 5 & 201010 & 005 & $0<2$ & 4 & 2500620 & 000 & 277 \\
\hline Pleasure from PA & q & 5 & 20184.0 & -0.05 & .963 & 4 & 358962.0 & -0.88 & $.37 /$ \\
\hline Escape from & $\sigma^{\alpha}$ & 4 & 188815 & 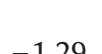 & 220 & 4 & 2615225 & 0 & 777 \\
\hline everyday live & q & 4 & 10001.0 & -1.23 & $.2 \angle 0$ & 4 & $304 J 22 . J$ & -0.25 & .112 \\
\hline Manoring strocs & 0 & 5 & 107000 & 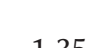 & 170 & 4 & 2171000 & 2 & P19 \\
\hline Managing stress & q & 4 & $18 / 88.0$ & -1.35 & $.1 / 8$ & 4 & $34 / 469.0$ & -2.03 & .042 \\
\hline Fulfilling the need & $0^{\pi}$ & 5 & 198685 & -034 & 736 & 4 & 3432115 & 6 & 014 \\
\hline for activity & q & 4 & 17000.0 & 0.07 & 170 & 4 & ט. & 2.70 & \\
\hline PA nromotion & 0 & 4 & 198690 & -032 & 749 & 3 & 3375585 & 297 & 003 \\
\hline - & ㅇ & 4 & 10000 & 0.02 & קד & 3 & (2) & 2.3 & .000 \\
\hline
\end{tabular}


$p<.001)$. The variable introduced in the second step explained an additional $4.00 \%$ of the variance in the number of hours devoted to PA, $F(1,2136)=$ 99.80, $p<.001$. In this step, significant predictors of PA intensity were: gender $(\beta=.04, p=.035)$, age $(\beta=-.10, p<.001)$, engagement in competitive sports $(\beta=.24, p<.001)$, and the motivational value of the goal $(\beta=.20, p<.001)$. Interaction effects introduced in the third step explained an additional $0.50 \%$ of the variance in the number of hours devoted to PA, $F(2,2134)=6.77, p<.001$. In this step, the significant predictors of PA intensity were age $(\beta=-.10$, $p<.001)$, the motivational value of the objective $(\beta=.13, p<.001)$, the interaction between the motivational value of the objective and gender $(\beta=.27$, $p=.021)$, and the interaction between the motivational value of the objective and engagement in competitive sports $(\beta=.41, p=.002)$. The entire model explained $14.00 \%$ of the variance in hours devoted to PA, $F(6,2134)=59.17, p<.001$. Table 5 contains the results of the applied regression analysis. Figure 1 presents the interaction effects that were being verified.

\section{DISCUSSION}

One can look at the objectives of physical activity from many perspectives. The aim of this study was to learn about the regulatory influence of motives on one's actions. The starting point for considerations

Table 4

Comparison of the scores of competitive sportsmen and amateurs divided by gender

\begin{tabular}{|c|c|c|c|c|c|c|c|c|c|}
\hline \multirow[t]{2}{*}{ Objectives } & \multirow{2}{*}{$\begin{array}{l}\text { Physical } \\
\text { activity }\end{array}$} & \multicolumn{4}{|c|}{0} & \multicolumn{4}{|c|}{ q } \\
\hline & & Me & $U$ & $Z$ & $p$ & $M e$ & $U$ & $Z$ & $p$ \\
\hline Health & $\begin{array}{c}\text { amateurs } \\
\text { competitive }\end{array}$ & $\begin{array}{l}4 \\
4\end{array}$ & 86335.0 & -0.49 & .625 & $\begin{array}{l}5 \\
4\end{array}$ & 82713.0 & -0.46 & .648 \\
\hline Physical fitness & $\begin{array}{c}\text { amateurs } \\
\text { competitive }\end{array}$ & $\begin{array}{l}5 \\
5\end{array}$ & 72862.0 & -4.48 & $<.001$ & $\begin{array}{l}4 \\
5\end{array}$ & 73317.5 & -3.02 & .003 \\
\hline $\begin{array}{l}\text { Company of } \\
\text { others }\end{array}$ & $\begin{array}{c}\text { amateurs } \\
\text { competitive }\end{array}$ & $\begin{array}{l}4 \\
4\end{array}$ & 72129.0 & -4.38 & $<.001$ & $\begin{array}{l}4 \\
4\end{array}$ & 71566.0 & -3.29 & $<.001$ \\
\hline Shapely body & $\begin{array}{c}\text { amateurs } \\
\text { competitive }\end{array}$ & $\begin{array}{l}4 \\
5\end{array}$ & 73011.5 & -4.22 & $<.001$ & $\begin{array}{l}5 \\
5\end{array}$ & 84219.0 & -0.05 & .959 \\
\hline Wellbeing & $\begin{array}{c}\text { amateurs } \\
\text { competitive }\end{array}$ & $\begin{array}{l}5 \\
5\end{array}$ & 78441.0 & -2.85 & .004 & $\begin{array}{l}5 \\
5\end{array}$ & 76259.5 & -2.33 & .020 \\
\hline Fashion for PA & $\begin{array}{c}\text { amateurs } \\
\text { competitive }\end{array}$ & $\begin{array}{l}3 \\
3\end{array}$ & 76375.5 & -3.15 & .002 & $\begin{array}{l}3 \\
3\end{array}$ & 75073.5 & -2.36 & .018 \\
\hline $\begin{array}{l}\text { Boosting } \\
\text { confidence }\end{array}$ & $\begin{array}{c}\text { amateurs } \\
\text { competitive }\end{array}$ & $\begin{array}{l}3 \\
4\end{array}$ & 72729.0 & -4.14 & $<.001$ & $\begin{array}{l}3 \\
3\end{array}$ & 76097.0 & -2.10 & .030 \\
\hline $\begin{array}{l}\text { Pleasure from } \\
\text { PA }\end{array}$ & $\begin{array}{c}\text { amateurs } \\
\text { competitive }\end{array}$ & $\begin{array}{l}4 \\
5\end{array}$ & 68885.0 & -5.55 & $<.001$ & $\begin{array}{l}4 \\
5\end{array}$ & 65135.5 & -5.16 & $<.001$ \\
\hline $\begin{array}{l}\text { Escape from } \\
\text { everyday live }\end{array}$ & $\begin{array}{c}\text { amateurs } \\
\text { competitive }\end{array}$ & $\begin{array}{l}4 \\
4\end{array}$ & 65726.0 & -6.13 & $<.001$ & $\begin{array}{l}4 \\
4\end{array}$ & 70228.5 & -3.63 & $<.001$ \\
\hline $\begin{array}{l}\text { Managing } \\
\text { stress }\end{array}$ & $\begin{array}{c}\text { amateurs } \\
\text { competitive }\end{array}$ & $\begin{array}{l}4 \\
5\end{array}$ & 68245.0 & -5.51 & $<.001$ & $\begin{array}{l}4 \\
4\end{array}$ & 75164.0 & -2.41 & .016 \\
\hline $\begin{array}{l}\text { Fulfilling } \\
\text { the need for } \\
\text { activity }\end{array}$ & $\begin{array}{c}\text { amateurs } \\
\text { competitive }\end{array}$ & $\begin{array}{l}4 \\
5\end{array}$ & 70798.0 & -4.84 & $<.001$ & $\begin{array}{l}4 \\
4\end{array}$ & 65376.0 & -4.93 & $<.001$ \\
\hline PA promotion & $\begin{array}{c}\text { amateurs } \\
\text { competitive }\end{array}$ & $\begin{array}{l}3 \\
4\end{array}$ & 65582.5 & -6.11 & $<.001$ & $\begin{array}{l}3 \\
4\end{array}$ & 57455.5 & -6.81 & $<.001$ \\
\hline
\end{tabular}


Table 5

Hierarchic analysis of regression, in which the explained variable was the intensity of $P A$

\begin{tabular}{|c|c|c|c|}
\hline \multirow[t]{2}{*}{ Step } & \multirow[t]{2}{*}{ Predictor } & \multicolumn{2}{|c|}{ Intensity of PA } \\
\hline & & $\beta$ & $\Delta R^{2}$ \\
\hline \multirow[t]{3}{*}{1} & Gender & .03 & $.097^{* *}$ \\
\hline & age & $-.11^{* *}$ & \\
\hline & competitive PA & $.27^{* *}$ & \\
\hline \multirow[t]{4}{*}{2} & Gender & $.04^{*}$ & $.040 * *$ \\
\hline & age & $-.10^{* *}$ & \\
\hline & competitive PA & $.24^{* *}$ & \\
\hline & motivational value & $.20^{* *}$ & \\
\hline \multirow[t]{6}{*}{3} & Gender & -.22 & $.005^{* *}$ \\
\hline & age & $-.10^{* *}$ & \\
\hline & competitive PA & -.15 & \\
\hline & motivational value & $.13^{* *}$ & \\
\hline & $\begin{array}{l}\text { interaction gender* } \\
\text { motivational value }\end{array}$ & $.27^{*}$ & \\
\hline & $\begin{array}{l}\text { interaction competitive } \\
\text { PA* }^{*} \\
\text { motivational value }\end{array}$ & $.41^{* *}$ & \\
\hline Total & $R^{2}$ & & $.143^{* *}$ \\
\hline
\end{tabular}

Note. gender $-0=$ male; 1 = female; competitive PA $-0=$ amateurs PA; 1 = competitive PA. ${ }^{*} p<.05 .{ }^{* *} p<.01$.

was the suggested influence of an objective on the activity oriented towards its accomplishment. "Behaviour measured in a predefined way is a criterion for the assessment of the motivational role of a goal" (Zaleski, 1991, p. 147).

Results confirmed the assumption about the diversity of motives for undertaking physical activity, dependent on gender. Among women, $28.20 \%$ declared that they engage in physical activity in order to achieve a fit physique. Additionally, some of the female participants considered health $(18.20 \%)$ and wellbeing (16.40\%) to be most important. Molanorouzi et al. (2015) reached similar conclusions in their research, indicating that women undertake physical activity most often in order to improve their appearance and physical fitness. Likewise, results regarding motives were presented in research by Lipowski (2006). The main goal of engaging in physical activity by women is the improvement of physique and its maintenance, as well as the improvement and maintenance of physical fitness. They undertake physical activity less often with health and wellbeing in mind. Motives guiding women may be associated with the need for acceptance and the desire to conform to the image of a woman as promoted by the media. A slim physique is considered beautiful and attractive (Czepczor

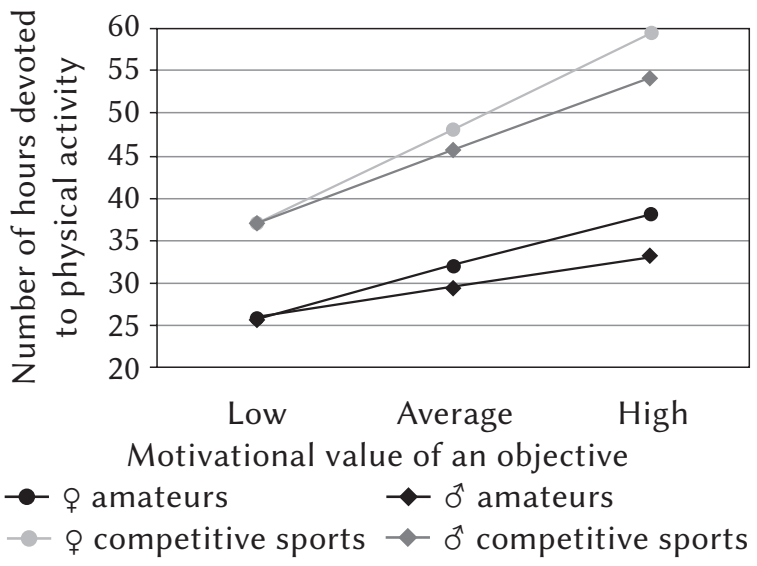

Figure 1. Effects of moderation of the relationship between the motivational value of an objective and the number of hours devoted to physical activity.

et al., 2016). This phenomenon is particularly visible in Western culture, where an attractive appearance is associated with satisfaction with life (Lipowska et al., 2007). Among men, the most important motive for undertaking physical activity was the improvement of physical ability and fitness (24.30\%); they less frequently engaged in PA with the improvement of physique $(17.50 \%)$ or wellbeing $(17.00 \%)$ in mind. This is in line with previous research, which indicates that the most common motive for undertaking physical activity among men is the desire to improve one's physical ability and fitness, and health and the desire to fulfil the need for activity is of secondary importance (Olszewski-Strzyżowski \& Dróżdż, 2014). Molanorouzi et al. (2015) came to different conclusions, indicating that the motivation to undertake PA among men is mastery and competition.

The motivational value of an objective is a significant predictor of the increase in PA (both in terms of number of devoted hours and methodicalness) $(\beta=.13, p<.001)$ - the number of hours devoted to PA increases together with the intensity of the motivational function of the objective. These results are in line with the Motivational Function of Objective Theory, and suggest the influence of the objective on behaviour oriented towards its achievement ( $\mathrm{Za}-$ leski, 1987). It is the effort (i.e. the physical activity undertaken) that is the most "sensitive" criterion for measuring the influence of importance, expectations, and conflict between objectives. The work towards achieving goals is more intensive if they are associated with long-term goals. A vision of the future thus constructed is a motivational factor. We can accurately describe the motivational role of goals when the criteria are goals that serve as means to achieve endpoints (Zaleski, 1987). Goals give a sense of freshness to activities, they make them more attractive and bring satisfaction to work aimed at achieving them. They cause the individual to voluntarily return to ac- 
tivities, just like they would to unfinished tasks - this is called the Zeigarnik effect (Savitsky et al., 1997). Rothman (2000), in turn, assumes in his model that people undertake goal-oriented activity because of a positive perspective that stimulates their imagination - a vision of the final result, the achieved goal (Rothman et al., 2000). A similar view is put forward by Csikszentmihalyi (1996), within the framework of the theory of flow.

Gender, as well as engagement in competitive sports, turned out to be moderators of the relation between the motivational function of a goal and the number of hours devoted to PA. The moderation effect assumes that the influence of independent variables is different for different levels of the moderator (Hayes, 2013). The influence of the motivational function of an objective on the number of hours devoted to PA is higher for women. It should be stressed that women identified the desire to improve their physique as the most important motive for engaging in PA. These results may be evidence of acting under the pressure of the imperfection of one's appearance, exerted by an environment in which one's body is always imperfect and which will always find a flaw in the body's appearance (Davis et al., 1995). Research suggests that a slim and slender female body ideal exists (Runfola et al., 2013; Benton \& Karazsia, 2015). Davis (1997) believes that even if a woman is satisfied overall with her appearance, she will express worry about some particular body part or body parts, which, in her opinion, require improvement. Nowadays, physical activities promoted among women are those aimed at beautifying one's body - such as those aimed at weight loss, and better musculature and appearance - instead of encouraging exercises that aim for mental and physical condition (Lipowski, 2006).

The influence of the motivational value of a goal on the number of hours devoted to PA is greater among individuals engaging in competitive sports in comparison to individuals who train for recreation. Most of the respondents who engaged in competitive sports at the time of the study engaged in PA when they were young. It could therefore be inferred that engaging in PA in one's youth encourages further participation in various forms of physical culture (Litwiniuk, 1994).

\section{CONCLUSIONS AND PRACTICAL IMPLICATIONS}

The motives for undertaking physical activity differed depending on the gender of the participant. For women, the most important motive turned out to be the improvement of physique, while men undertake PA in order to improve their physical fitness. Moreover, the results suggest that the number of hours devoted to PA increase as the motivational value of the objective increases. Additionally, gender and engagement in competitive sports turned out to be the moderators of this relationship. Women who engage in competitive sports are characterised by higher motivational values of objectives than men. Objectives explain the undertaking of particular activities to a large extent, as well as changes in their intensity and duration. These results provide useful knowledge for people who engage in sports, allowing the assessment of motives for undertaking physical activity as well as for conscious influence by increasing motivation and setting realistic objectives.

\section{REFERENCES}

Aaltonen, S., Rottensteiner, M., Kaprio, J., \& Kujala, U. (2014). Motives for physical activity among active and inactive persons in their mid-30s. Scandinavian Journal of Medicine \& Science in Sports, 24, 727-773. doi: 10.1111/sms. 12040

Ames, C. (1992). Achievement Goals, Motivational Climate, and Motivational Processes. In G. Roberts (Ed.), Motivation in Sport and Exercise (pp. 161-176). Champaign: Human Kinetics.

Bandura, A. (1989). Self-regulation of motivation and action through internal standards and goal system. In L. A. Pervin (Ed.), Goal concepts in personality and social psychology (pp. 19-85). New York: Psychology Press.

Benton, C., \& Karazsia, B. T. (2015). The effect of thin and muscular images on women's body satisfaction. Body image, 13, 22-27. doi: 10.1016/j.bodyim.2014.11.001

Blecharz, J. (2002). Jak motywować mistrzów? [How to motivate champions?]. Sport Wyczynowy, 9, 453-454.

Carifio, J., \& Perla, R. J. (2007). Ten common misunderstandings, misconceptions, persistent myths and urban legends about Likert scales and Likert response formats and their antidotes. Journal of Social Sciences, 3, 106-116.

CBOS. (2013). Aktywność fizyczna polaków [Physical activity of Polish people]. CBOS online. Retrieved from http://www.cbos.pl/SPISKOM. POL/2013/K_129_13.PDF

Czepczor, K., Kościcka, K., \& Brytek-Matera, A. (2016). Społeczno-kulturowe postawy wobec własnego wyglądu i niezadowolenie z ciała u kobiet i mężczyzn w okresie późnej adolescencji [The sociocultural attitudes towards appearance and body dissatisfaction among late adolescence: a pilot study]. Polskie Forum Psychologiczne, 21, 364-377. doi: 10.14656/PFP20160303

Csikszentmihalyi, M. (1996). Flow and the psychology of discovery and invention. New York: Harper Collins Publishers.

Davis, C., Fox, J., Brewer, H., \& Ratusny, D. (1995). Motivations to exercise as a function of personality 
characteristics, age, and gender. Personality and individual differences, 19, 165-174.

Deci, E., \& Ryan, R. (1985). Intrinsic Motivation and Self-Determination in Human Behaviour. New York: Plenum.

Franken, R. E. (2005). Psychologia motywacji [Human motivation]. Gdańsk: Gdańskie Wydawnictwo Psychologiczne.

Hayes, A. F. (2013). Introduction to mediation, moderation, and conditional process analysis: A regression-based approach. New York: Guilford Press.

Kozielecki, J. (2000). Koncepcje psychologiczne człowieka [Psychological concepts of human]. Warszawa: Wydawnictwo Akademickie Żak.

Kozielecki, J. (1987). Koncepcja transgresyjna człowie$k a$ [Transgressive concept of human]. Warszawa: Wydawnictwo Naukowe PWN.

Kreitler S., \& Kreitler, H. (1994). Goals and plans: The perspective of cognitive orientation. In Z. Zaleski (Ed.), Psychology of Future Orientation (pp. 141156). Lublin: Towarzystwo Naukowe KUL.

Lipowska, M., Lipowski, M., \& Jankowska, A. (2007). Determinants of Physical Attractiveness among Polish and Spanish Youth. In A. Chybicka \& M. Kaźmierczak (Eds.), Appreciating diversity cultural and gender issues - vol II (pp. 293-310). Kraków: Oficyna Wydawnicza Impuls.

Lipowski, M. (2006). Rekreacja ruchowa kobiet jako zachowanie prozdrowotne - uwarunkowania a motywy uczestnictwa [Physical activity of women as pro-health behaviour - determinants and motives of participation]. Gdańsk: Wydawnictwo Uczelniane Akademii Wychowania Fizycznego i Sportu.

Lipowski, M., \& Zaleski, Z. (2015). Inventory of Physical Activity Objectives (IPAO) - a new method in measuring motives for physical activity and sport. Health Psychology Report, 3, 47-58. doi: 10.5114/ hpr.2015.49462

Li, F. (1999). The exercise motivation scale: its multifaceted structure and construct validity. Journal of Applied Sport Psychology, 11, 97-115. doi: 10.1080/10413209908402953

Litwiniuk, A. (1994). Uczestnictwo w sporcie a uczestnictwo w rekreacji fizycznej byłych Sportowców [Participation in sport and participation in physical recreation of former athletes]. Kultura Fizyczna, 3, 28-29.

Markland, D., \& Hardy, L. (1993). The exercise motivations inventory: preliminary development and validity of a measure of individuals' reasons for participation in regular physical exercise. Personality \& Individual Differences, 15, 289-296.

Molanorouzi, K., Khoo, S., \& Morris, T. (2015). Motives for adult participation in physical activity, BMC Public Health, 15, 66-78. doi: 10.1186/s12889015-1429-7
Molanorouzi, K., Khoo, S., \& Morris T. (2014). Validating the Physical Activity and Leisure Motivation Scale (PALMS). BMC Public Health, 14, 909-921.

Nuttin, J. (2014). Future time perspective and motivation: Theory and research method. Psychology Press.

Olszewski-Strzyżowski, J., \& Drożdż, R. (2014). Motywy podejmowania aktywności fizycznej przez mieszkańców Elbląga [Motives for physical activity involvement of inhabitants of Elbląg]. Rozprawy Naukowe Akademii Wychowania Fizycznego we Wroctawiu, 47, 124-130.

Pelletier, L. G., Tuson, K. M., Fortier, M. S., Vallerand, R. J., Briere, N. M., \& Blais, M. R. (1995). Toward a new measure of intrisic motivation, extrinsic motivation, and amotivation in Sports: The Sport Motivation Scale (SMS). Journal of Sport and Exercise Psychology, 17, 35-53.

Pervin, L. A. (1993). Personality theory and research. New York: Wiley.

Rogers, H., Morris, T., \& Moore, M. (2008). A qualitative study of the achievement goals of recreational exercise participants. The Qualitative Report, 13, 706-734.

Rothman, A. J. (2000). Toward a theory-based analysis of behavioral maintenance. Health Psychology, 19, 64-69. doi: 10.1037//0278-6133.19.1

Runfola, C. D., Von Holle, A., Trace, S. E., Brownley, K. A., Hofmeier, S. M., Gagne, D. A., \& Bulik, C. M. (2013). Body dissatisfaction in women across the lifespan: Results of the UNC-SELF and gender and body image (GABI) studies. European Eating Disorders Review, 21, 52-59. doi: 10.1002/ erv.2201

Ryan, R., Frederick, C., Lepes, D., Rubio, N., \& Sheldon, K. (1997). Intrinsic motivation and exercise adherence. International Journal of Sport Psychology, 28, 235-254.

Savitsky, K., Medvec, V. H., \& Gilovich, T. (1997). Remembering and regretting: The Zeigarnik effect and the cognitive availability of regrettable actions and inactions. Personality and Social Psychology Bulletin, 23, 248-257. doi: 10.1177/ 0146167297233004

Tomaszewski, T. (1979). Wstęp do psychologii [Introduction to Psychology]. Warszawa: Wydawnictwo Naukowe PWN.

Zaleski, Z. (1991). Psychologia zachowań celowych [Psychology of goal-directed behaviour]. Warszawa: Wydawnictwo Naukowe PWN.

Zizzi, S. J., Keeler, L. A., \& Watson, J. C. (2006). The interaction of goal orientation and stage of change on exercise behavior in college students. Journal of Sport Behavior, 29, 96-110. 